\title{
Source-reservoir chart for tight oil sweet spots evaluation and its application in Permian of Jimsar Sag, Junggar Basin
}

\author{
Lufeng Zhan ${ }^{1} \cdot$ Bincheng Guo ${ }^{1}$ Yuanjiang Yu ${ }^{1}$ Junwen $\mathrm{Hu}^{1} \cdot$ Shejiao Wang ${ }^{1}$
}

Received: 4 September 2018 / Accepted: 20 March 2019 / Published online: 28 March 2019

(c) The Author(s) 2019

\begin{abstract}
Sweet spots control the production of the tight oil reservoir, so sweet spots evaluation is a critical work for tight oil exploration and development. This paper proposes a source-reservoir chart method for tight oil sweet spots evaluation and an application in Permian of Jimsar Sag, Junggar Basin. Firstly, the evaluation chart is plotted based on the relationships between the TOC and Ro parameters of source rocks, the porosity and the oil saturation of reservoirs through the experimental data of hydrocarbon generation simulation and mercury injection. Secondly, according to the evaluation criteria of TOC, Ro of source rock and porosity, oil saturation of reservoir in the study area, the chart is divided into three sweet spots zones and a nonsweet spots zone. Finally, each grid of the study area is assigned parameters and plotted in the chart of different zones, and the sweet spots are mapped. Production data show the reliability of the evaluation results. This method provides a convenient and efficient procedure for evaluating sweet spots of tight oil based on integrating the quality of source rocks and reservoirs.
\end{abstract}

Keywords Tight oil $\cdot$ Sweet spots $\cdot$ Evaluation $\cdot$ Source rock $\cdot$ Reservoir $\cdot$ Jimsar sag

\section{Introduction}

Tight oil is one kind of unconventional oil and gas resources. It refers to the oil accumulation in tight reservoirs from sandwiched or adjacent source rocks without long-distance migration. The property of the tight reservoir is commonly less than $1 \mathrm{mD}$ of air permeability or $0.1 \mathrm{mD}$ of overpressure permeability (Du et al. 2016). After years of exploration practice and theoretical understanding of tight oil, many researchers have proposed that overpressure caused by hydrocarbon generation is the main driving force for primary migration and tight oil accumulation (Nordeng 2009; Li and LI 2010; Feng et al. 2011; Pang et al. 2016). The mechanism of hydrocarbon generation and accumulation in tight reservoir can be summarized as follows: As the burial depth of source rocks increases, the formation temperature and pressure gradually increase, and oil will be generated when the organic matter reaches a certain maturity. When oil is generated, the volume increases, but at this time, the

Lufeng Zhan

zhanlufeng@petrochina.com.cn

1 Research Institute of Petroleum Exploration and Development (RIPED), PetroChina, Beijing, People's Republic of China source rock is already quite tight, and the oil is squeezed and not easy to be discharged, so the fluid pressure increases in the form of accumulated elastic energy. When the pressure is high enough to produce micro-fractures in the source rock, pore fluid is expelled through the micro-fractures (Xu et al. 1998). The adjacent reservoirs are also tight due to burial and compaction, with small pore throats and large capillary resistance, and the buoyancy migration of oil is limited. Therefore, oil mainly relies on hydrocarbon generation overpressure to overcome the capillary resistance of tight reservoirs, thus entering and forming tight oil reservoirs. From the view of the mechanism of hydrocarbon generation and accumulation in tight reservoir, the sweet spots of tight reservoir are jointly controlled by the quality of source rocks and reservoirs (Yang et al. 2015). The quality of source rock and formation conditions control the overpressure caused by hydrocarbon generation, and the quality of reservoir controls the difficulty of oil accumulation.

To evaluate the quality of source rocks, pyrolysis $\mathrm{S} 1+\mathrm{S} 2$, TOC and HI are important parameters. Pyrolysis is the cracking of organic matter by high temperature under the condition of no oxygen. S1 and S2 are measurements of the free hydrocarbons and the remaining hydrocarbon potential in a rock. Pyrolysis $\mathrm{S} 1+\mathrm{S} 2$ is the sum of $\mathrm{S} 1$ and $\mathrm{S} 2$, and it can be used to evaluate the hydrocarbon potential. 
TOC is the total organic carbon of a source rock unit, and the amount of organic carbon determines the ability to generate hydrocarbons in a source rock. HI, hydrogen index, represents the amount of hydrogen relative to the amount of organic carbon present in a source rock (Law 1999). These parameters can be measured and calculated by Rock-Eval analysis. Formation conditions of pressure, long geological time, burial history and tectonics mainly control the maturity of source rocks. The maturity of source rocks is mainly evaluated by $R o$ parameter. $R o$ is vitrinite reflectance, which measures the percentage of incident light reflected from the surface of vitrinite particles. To evaluate the quality of reservoirs, porosity and permeability are two key parameters.

Many researchers have carried out studies on the evaluation of unconventional sweet spots zones (Yang et al. 2012; Zhou and Jiao 2012; Aliouane and Ouadfeul 2014; Liu 2015; Yang et al. 2015; Zou et al. 2015; Tian et al. 2016). However, these studies only proposed the evaluation methods and criteria of source rocks and reservoirs, respectively, and there is not much discussion about how to integrate the quality of source rocks and reservoirs to evaluate sweet spots.

This paper focuses on two parts: Firstly, how much is the increase of fluid pressure caused by hydrocarbon generation in source rocks? Second, how high oil saturation is formed in tight reservoir under different oil charging pressures and reservoir properties. There are mainly two research methods of overpressure caused by hydrocarbon generation: theoretical calculation and physical simulation. Based on the hydrocarbon generation kinetics theory and the state parameters of various substances such as oil, water, rocks, the theoretical calculation method establishes an idealized physical model to calculate the overpressure values in different geological backgrounds and stages of evolution. Many researchers have proposed theoretical formulas for calculating the overpressure caused by hydrocarbon generation of source rock (Berg and Gangi 1999; Guo et al. 2011; Ju et al. 2014). Most of these formulas are based on the principle of conservation of mass and the equation of state of matter; however, the overpressure caused by hydrocarbon generation in source rocks is a complicated physical and chemical process. Under the current conditions, many factors are difficult to be accurately considered by mathematical methods (Zhang et al. 2018). The prediction of interwell sweet spots in exploration mainly relies on seismic data, which cannot obtain the required parameters of the formula. Physical simulation selects actual hydrocarbon source rock samples, simulates the kerogen-to-oil conversion process under laboratory conditions and directly measures the pressure change caused by this transformation process in a closed system. In this paper, the physical simulation data are mainly used to empirically fit the overpressure caused by hydrocarbon generation. The relationship between oil charging pressure, porosity and oil saturation in tight reservoirs can be obtained by mercury injection experiments.

The research process of this paper is as follows: Firstly, the relationship between the TOC and Ro parameters of source rocks and the overpressure is established through the experimental data of hydrocarbon generation. Then, based on the mercury injection experimental data in the study area, the capillary resistance is converted into corresponding source rock parameters by using the above relations. Finally, the TOC and $R o$ of hydrocarbon source rocks are taken as the $\mathrm{X}$-axis, reservoir porosity as the $\mathrm{Y}$-axis and oil saturation curve as the evaluation grade to establish the evaluation chart, which is used to predict the area with good quality of hydrocarbon source rocks and reservoirs, so as to guide the optimization of exploration sweet spots. This workflow provides a new method for the optimization of tight oil sweet spots in other basins or regions.

\section{Source-reservoir chart building}

\section{Samples and experimental methods}

The laboratory data for this study are based on Ma et al. (2013). They conducted a simulation experiment of hydrocarbon generation by cooking the immature lacustrine source rock samples. The four samples are acquired from the four wells in the Eocene Shahejie Formation of the Qikou Sag, Bohaiwan Basin. The organic matter types of the samples are $\mathrm{II}_{1}$ and $\mathrm{II}_{2}$, the TOC is from $1.9 \%$ to $4.72 \%$ and the hydrogen index (HI) is from $201.92 \mathrm{mg} / \mathrm{g}$ to $669.16 \mathrm{mg} / \mathrm{g}$. Geochemical characteristics of the four samples are shown in Table 1. These geochemical characteristics are similar to the study area.
Table 1 Geochemical characteristics of the four samples (from Ma et al., 2013)

\begin{tabular}{lllllllll}
\hline $\begin{array}{l}\text { Mud- } \\
\text { stone } \\
\text { sample }\end{array}$ & Depth (m) & TOC $(\%)$ & $T_{\max }\left({ }^{\circ} \mathrm{C}\right)$ & $S_{1}\left(\mathrm{mg} \cdot \mathrm{g}^{-1}\right)$ & $S_{2}\left(\mathrm{mg} \cdot \mathrm{g}^{-1}\right)$ & $H I\left(\mathrm{mg} \cdot \mathrm{g}^{-1}\right)$ & $R o(\%)$ & $\begin{array}{l}\text { Organic } \\
\text { matter } \\
\text { types }\end{array}$ \\
\hline $1 \#$ & 1937.78 & 4.72 & 424 & 0.96 & 31.58 & 669.16 & 0.38 & $\mathrm{II}_{1}$ \\
$2 \#$ & 1963 & 2.27 & 423 & 0.57 & 14.14 & 622.95 & 0.45 & $\mathrm{II}_{1}$ \\
$3 \#$ & 3401.5 & 4.5 & 439 & 1.18 & 14.52 & 322.63 & 0.67 & $\mathrm{II}_{2}$ \\
$4 \#$ & 2889.9 & 1.9 & 436 & 0.24 & 3.84 & 201.92 & 0.53 & $\mathrm{II}_{2}$ \\
\hline
\end{tabular}


In the process of hydrocarbon generation simulation, firstly, the sample was compressed into a cylinder with a diameter of $3.8 \mathrm{~cm}$ and a mass of 90-150 g, during which distilled water was saturated. Then, the sample was placed in a sealed high-temperature autoclave, and the static rock pressure was applied for compaction. Secondly, blank experiments were carried out. The sample chamber was filled with quartz sand, the same amount of distilled water as the saturated source rock samples, and placed in a closed high-temperature autoclave. The temperature rose at a rate of $50{ }^{\circ} \mathrm{C} / \mathrm{h}$ to $350{ }^{\circ} \mathrm{C}, 400{ }^{\circ} \mathrm{C}$ and $450{ }^{\circ} \mathrm{C}$, respectively. When the water pressure value remained constant for more than $1 \mathrm{~h}$, the water thermal expansion pressure was recorded. Finally, the hydrocarbon-generating pressurization simulation test at different temperatures was carried out. The compressed cylinder samples were placed in a closed high-temperature autoclave. The temperature rose to $350{ }^{\circ} \mathrm{C}, 400{ }^{\circ} \mathrm{C}$ and $450{ }^{\circ} \mathrm{C}$, respectively, at the same rate of $50{ }^{\circ} \mathrm{C} / \mathrm{h}$. Then, the temperature was kept constant for $24 \mathrm{~h}$ to record the fluid pressure. The fluid pressure minus the water thermal pressure is called hydrocarbon generation pressure. The experimental equipment and methods were described in detail by Ma et al. (2013).

\section{Overpressure caused by hydrocarbon generation empirical fitting}

Based on the laboratory data (Table 2), the overpressure caused by the hydrocarbon generation of the source rock is related to the mass of the experimental samples; therefore, the overpressure per unit mass is calculated and fitted with source rock parameters.

The overpressure per unit mass equation can be expressed as Eq. (1), and the correlation coefficient can reach 0.7225
(Fig. 1). The source formation overpressure per unit area can be expressed as Eq. (2):

$\Delta P=0.0202 \mathrm{TOC} \cdot R o+0.0308$

$P_{\mathrm{f}}=\Delta P \rho_{\mathrm{m}} H_{\mathrm{m}}$

where $\Delta P$ is the overpressure per unit mass $(\mathrm{MPa} / \mathrm{g})$, TOC is total organic carbon content $(\%), R o$ is vitrinite reflectance $(\%), P_{\mathrm{f}}$ is the source formation overpressure per unit area (MPa), $\rho_{\mathrm{m}}$ is the density of mudstone $\left(\mathrm{g} / \mathrm{cm}^{3}\right), H_{\mathrm{m}}$ is the thickness of mudstone $(\mathrm{cm})$.

\section{Pressure data conversion to source rock parameter}

In the environment where the hydrocarbon source rock is matured, the generated crude oil enters the adjacent reservoir of different properties and forms different oil saturation reservoirs. According to the mercury injection experiment of the Lucaogou Formation (Ma and Zhang 2017), the

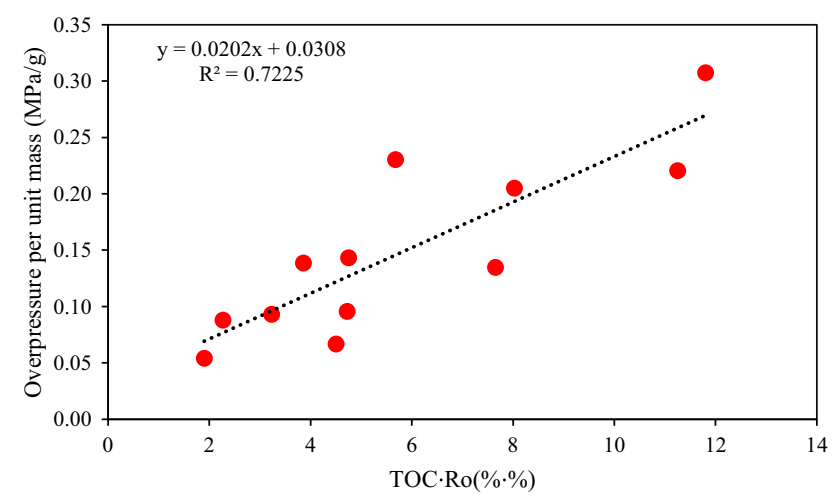

Fig. 1 Relationship between the source rock parameters combination and the overpressure per unit mass caused hydrocarbon generation
Table 2 Hydrocarbon generation simulation experimental data sheet (calculated from Ma et al., 2013)

\begin{tabular}{|c|c|c|c|c|c|c|}
\hline $\begin{array}{l}\text { Mud- } \\
\text { stone } \\
\text { sample }\end{array}$ & TOC (\%) & $\begin{array}{l}\text { Simulation } \\
\text { temperature } \\
\left({ }^{\circ} \mathrm{C}\right)\end{array}$ & $\begin{array}{l}\text { Simula- } \\
\text { tion Ro } \\
(\%)\end{array}$ & $\begin{array}{l}\text { Sample } \\
\text { mass }(g)\end{array}$ & $\begin{array}{l}\text { Overpressure caused by } \\
\mathrm{HC} \text { generation (MPa) }\end{array}$ & $\begin{array}{l}\text { Overpressure per } \\
\text { unit mass }(\mathrm{MPa} / \mathrm{g})\end{array}$ \\
\hline \multirow[t]{3}{*}{$1 \#$} & \multirow[t]{3}{*}{4.72} & 350 & 1 & 142 & 13.6 & 0.096 \\
\hline & & 400 & 1.7 & 132 & 27.1 & 0.205 \\
\hline & & 450 & 2.5 & 92 & 28.3 & 0.308 \\
\hline \multirow[t]{3}{*}{ 2\# } & \multirow[t]{3}{*}{2.27} & 350 & 1 & 142 & 12.5 & 0.088 \\
\hline & & 400 & 1.7 & 132 & 18.3 & 0.139 \\
\hline & & 450 & 2.5 & 92 & 21.2 & 0.230 \\
\hline \multirow[t]{3}{*}{$3 \#$} & \multirow[t]{3}{*}{4.5} & 350 & 1 & 142 & 9.5 & 0.067 \\
\hline & & 400 & 1.7 & 132 & 17.8 & 0.135 \\
\hline & & 450 & 2.5 & 92 & 20.3 & 0.221 \\
\hline \multirow[t]{3}{*}{ 4\# } & \multirow[t]{3}{*}{1.9} & 350 & 1 & 142 & 7.7 & 0.054 \\
\hline & & 400 & 1.7 & 132 & 12.3 & 0.093 \\
\hline & & 450 & 2.5 & 92 & 13.2 & 0.143 \\
\hline
\end{tabular}


Table 3 Parameters of calculated TOC times $R o$ for different porosity and oil saturation values

\begin{tabular}{|c|c|c|c|c|c|}
\hline \multirow[t]{2}{*}{$\begin{array}{l}\text { Reservoir } \\
\text { sample }\end{array}$} & \multirow[t]{2}{*}{ Porosity (\%) } & \multicolumn{4}{|c|}{$\begin{array}{l}\text { Calculated TOC times Ro parameter (\% } \\
\%)\end{array}$} \\
\hline & & So $20 \%$ & So $40 \%$ & So $60 \%$ & So $80 \%$ \\
\hline 1 & 17 & 0.54 & 0.56 & 0.58 & 0.68 \\
\hline 2 & 14.65 & 0.64 & 0.77 & 0.94 & 1.50 \\
\hline 3 & 10.75 & 1.42 & 2.03 & 2.31 & 3.68 \\
\hline 4 & 6.3 & 2.64 & 3.45 & 4.58 & 8.32 \\
\hline 5 & 3.55 & 3.26 & 4.58 & 6.67 & 14.17 \\
\hline
\end{tabular}

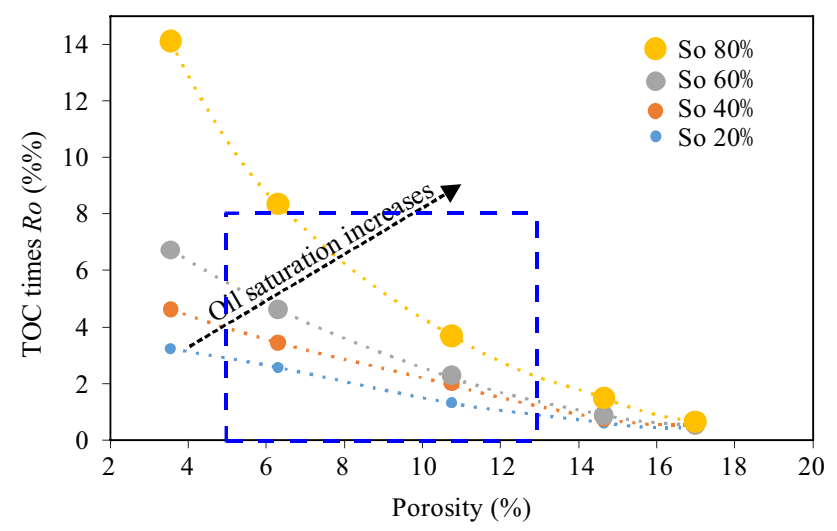

Fig. 2 Tight oil source-reservoir chart. The blue dashed box area is used in Fig. 8

pressure data required for reservoirs with different porosities to achieve certain oil saturation can be obtained. The inverse calculation is made by the empirical fitting Eq. (1) and (2), where $P_{f}$ equals the mercury injection pressure in Table 3, $\rho_{\mathrm{m}}$ is the density of mudstone of $2.56 \mathrm{~g} / \mathrm{cm}^{3}, \mathrm{H}_{\mathrm{m}}$ is the average thickness of the source rock in the upper sweet spots of $245 \mathrm{~cm}$ and the TOC times Ro parameter calculated by the pressure is in Table 3.

\section{Source-reservoir chart building}

Based on the data in Table 3, serials of oil saturation data are plotted in the coordinate of porosity and TOC times $R o$ parameters to build the source-reservoir chart (Fig. 2). In the lower left corner of the chart, the oil saturation of the tight reservoir, formed by the combination of the low value of the porosity and TOC times Ro parameters, is relatively low. As the porosity and TOC times Ro parameters increase, the oil saturation gradually increases. At the same saturation dotted line, the configuration relationships of different porosity and TOC times Ro parameter values indicate that different quality of the source and reservoir configurations can also form the same tight oil saturation.

Since the chart is established through samples in the laboratory, the evaluation results also require the quality control of the wells already drilled to verify the reliability of the results.

\section{Application}

\section{Geological background of the study area}

The Junggar Basin is a Permian-Pleistocene lacustrine basin in the Xinjiang Province, Northwest of China. The Jimsar Sag is located in the southwestern part of the eastern uplift of the Junggar Basin. It is $150 \mathrm{~km}$ away from Urumqi City and covers an area of about $1300 \mathrm{~km}^{2}$. It is a half-graben which is controlled by faults on north-west-south three sides (Fig. 3). The main tight oil exploration target formation is the Middle Permian Lucaogou Formation. The formation is generally characterized by a monoclinic structure that slopes westward. The main part of the formation has a dip angle of $3^{\circ}$ to $5^{\circ}$ and a thickness of 25 to $350 \mathrm{~m}$. The top of the formation is erosion, which forms an unconformity surface with the overlying Wutonggou Formation (Kuang et al. 2015). The sedimentary environment of the Lucaogou Formation period is saline lake with fine sediments. It is dominated by the delta front, the lacustrine carbonate beach bar and the lacustrine mudstone (Zhang et al. 2017), and the lithologies are clastic and carbonate rock which are two major categories. There are two sets of tight oil sweet spots in the vertical direction. The upper sweet spots section is the focus of exploration. The lithology of the upper sweet spots section is clastic dolomite, feldspar fine sandstone and dolomitic sandstone with an average thickness of $36.8 \mathrm{~m}$. On the horizontal direction, the upper sweet spots area is mainly developed in the central of the depression, and the surrounding is erosion. The sweet spots bed and the mudstone bed are distributed in layers, the lateral heterogeneity is strong and the fracture is underdeveloped.

\section{Characteristics of source rocks and reservoirs}

The source rock lithology of the Lucaogou Formation is dominated by mudstone, dolomitic mudstone, lime mudstone and sandy mudstone. The source rock is evaluated by Rock-Eval pyrolysis. The kerogen type is I-II, the total organic carbon (TOC) is $0.16 \%-12.31 \%$ and the average is $3.65 \%$. The pyrolysis $\mathrm{S} 1+\mathrm{S} 2$ distribution range is $0.05-76.6 \mathrm{mg} / \mathrm{g}$, with an average of $25.03 \mathrm{mg} / \mathrm{g}$. Hydrogen index (HI) ranges from 4.8 to $792.21 \mathrm{mg} / \mathrm{g}$, with an average 

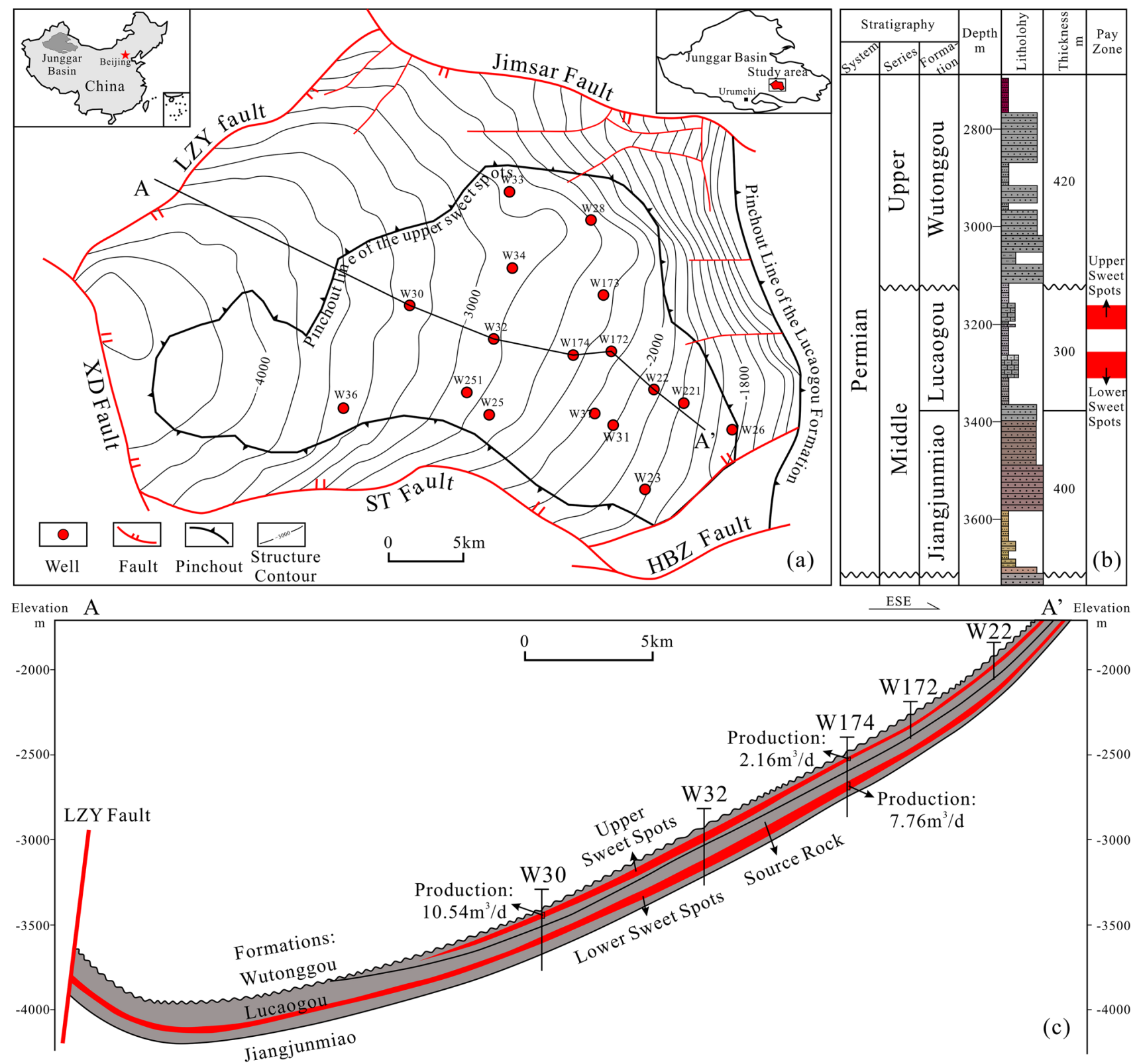

A' Elevation

Fig. 3 a Lucaogou Formation top structure map, b stratigraphy column of Middle and Upper Permian, main tight oil exploration target is Lucaogou formation, $\mathbf{c}$ well section from west to east

of $480.5 \mathrm{mg} / \mathrm{g}$. Vitrinite reflectance $(R o)$ is $0.58 \%-1.0 \%$, with an average of $0.72 \%$ (Fig. 4).

The reservoir lithologies of the Lucaogou Formation are transitional lithologies of clastic and carbonate rocks. The clastic rocks are argillaceous siltstone, dolomitic siltstone, lime siltstone and siltstone. The carbonate rocks include calcitic dolomite, sandy dolomite and muddy dolomite. The average overpressure porosity is $10.8 \%$, and the overpressure permeability is $0.001 \times 10^{-3}-0.6 \times 10^{-3} \mu \mathrm{m}^{2}$ (Fig. 5). The type of reservoir space is dominated by intergranular and intragranular dissolved pores with an average pore diameter of $67.53 \mu \mathrm{m}$ and an average throat radius of $3.08 \mu \mathrm{m}$.

The oil saturation of the sweet spots sections of the Well W174 is found to be positively associated with the TOC of mudstones and the reservoir porosity. When the TOC of the surrounding source rock within $1 \mathrm{~m}$ is relatively high, 

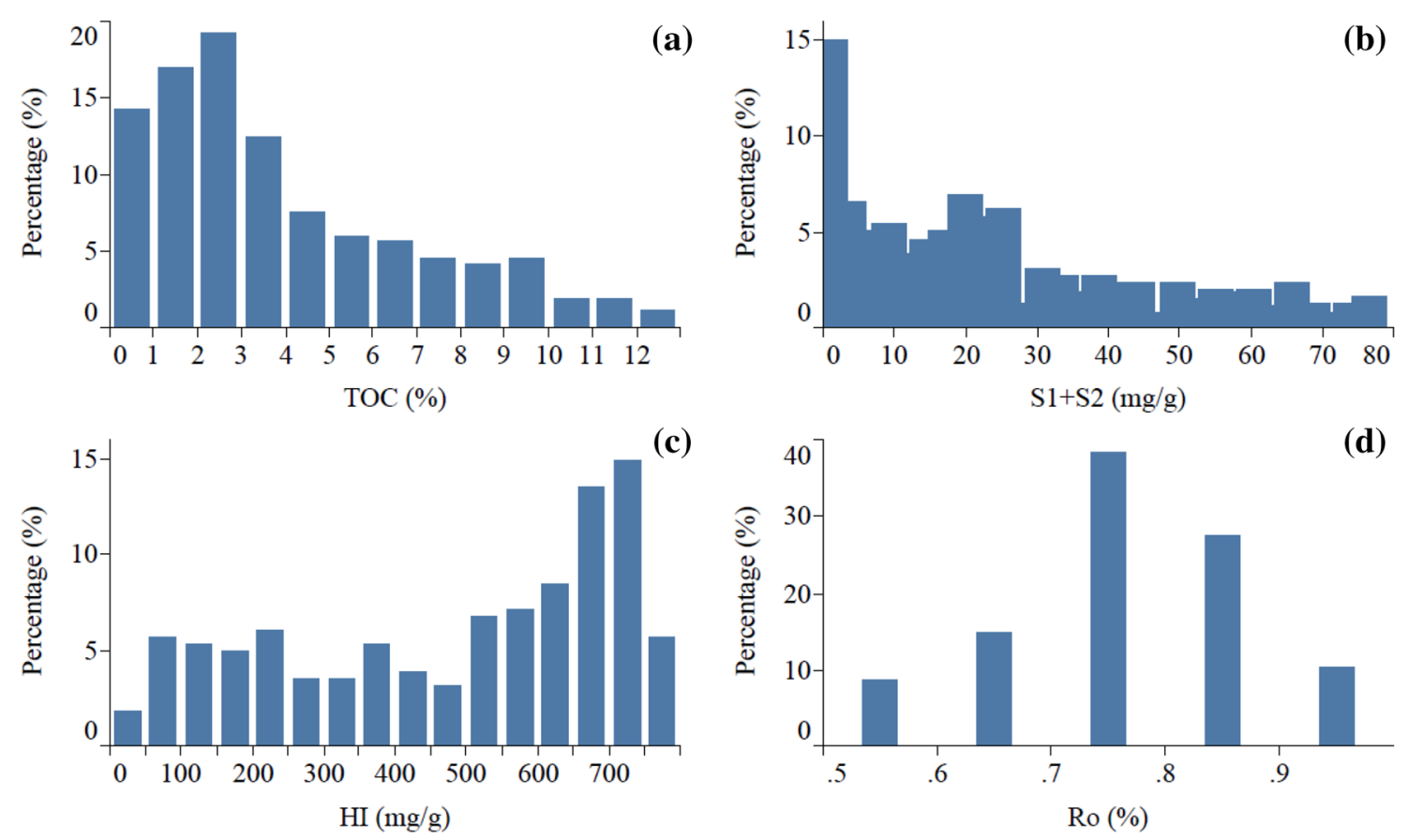

Fig. 4 Geochemical indicators of source rocks in the Lucaogou Formation a TOC, b pyrolysis S1 + S2, c hydrogen index, $\mathbf{d}$ vitrinite reflectance
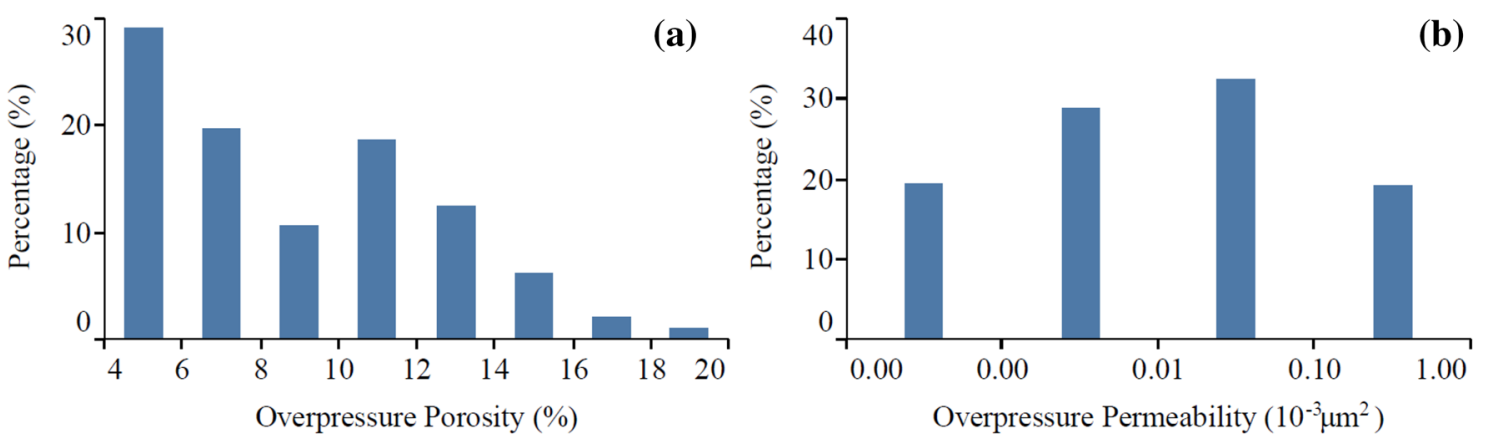

Fig. 5 Overpressure porosity (a) and permeability (b) distribution of reservoirs in the Lucaogou Formation

the reservoir oil saturation is high, vice versa (Fig. 6), and reservoir oil saturation has a correlation coefficient of 0.639 with porosity (Fig. 7).

\section{Sweet spots evaluation chart of the study area}

According to the range of the reservoir porosity and source rocks TOC times $R o$ in the study area, part of the chart area is selected from Fig. 2, and the oil saturation curves of $40 \%$ and $80 \%$ are selected. The evaluation criteria of TOC times $R o$ of source rock and porosity, oil saturation of reservoir are used to divided the chart into several zones (Fig. 8). The tight oil exploration practice in the
Jimsar Sag shows that the lower limit of the porosity of the sweet spots reservoir is $6 \%$, the lower limit of TOC is $1.3 \%$, the lower limit of $R o$ is $0.5 \%$ and the lower limit of oil saturation is $40 \%$ (Kuang et al. 2014); the areas below these limits (porosity less than $6 \%$, oil saturation less than $40 \%$, TOC times Ro parameter lower than $0.65 \%$ $\%)$ are non-sweet zones. Above the lower limits, the chart is divided into three zones by porosity and oil saturation parameters of $8 \%$ and $80 \%$. In the class I zone, the porosity is greater than $8 \%$ and the oil saturation is greater than $80 \%$; in the class II zone, the porosity is greater than $8 \%$ and the oil saturation is between $40 \%$ and $80 \%$; and in the 


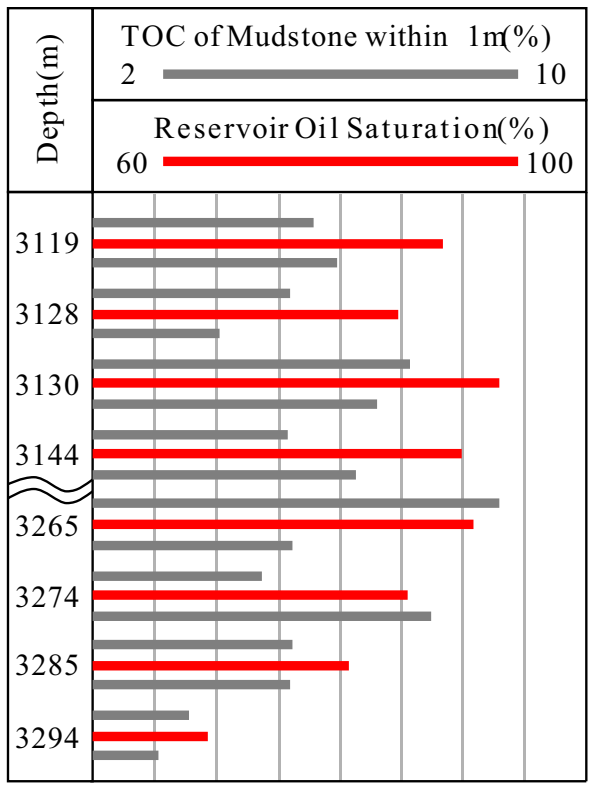

Fig. 6 TOC of mudstone within $1 \mathrm{~m}$ and reservoir oil saturation of the Lucaogou Formation in W174 well

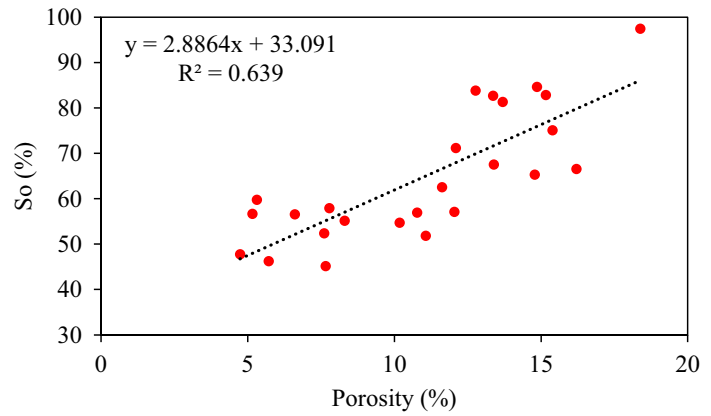

Fig. 7 Relationship between the reservoir oil saturation and porosity of the Lucaogou Formation in W174 well

class III zone, the porosity is between $6 \%$ and $8 \%$ and the oil saturation is between $40 \%$ and $80 \%$.

\section{Tight oil sweet spots evaluation results}

Based on the reservoir porosity and the source rock TOC, $R O$ distribution map of seismic prediction of the target layer in the study area, we divide the study area into $50 * 50 \mathrm{~m}$ grids. Each grid is assigned two parameters: TOC times $R o$ and porosity. These two parameters are then used as $\mathrm{X}$ and $\mathrm{Y}$ to plot the scatter points by cross mark in Fig. 8. Grids that fall into class I are painted red, fall into class II yellow, fall into class III green and fall into non-sweet blue, and then the planar distribution of the Class I, II, and III sweet spots zones can be displayed (Fig. 9). The Class I sweet spots zone is mainly distributed in the middle and southeast of the study area, with an area of $171.8 \mathrm{~km}^{2}$; The Class II sweet spots zone is distributed in the periphery of class I, with an area of $173.9 \mathrm{~km}^{2}$; The Class III sweet spots area has a small distribution range of $85.7 \mathrm{~km}^{2}$, mainly located in the surrounding of class II.

In 2014, the development pilot test area was located around Well W174 and four horizontal wells of two pads, H01-H04, were drilled from Class II to I sweet spots areas. The daily peak productions of the horizontal wells were quite different from 4.3 to $16.5 \mathrm{t} / \mathrm{d}$. In 2016, two horizontal experimental wells $\mathrm{H} 21$ and $\mathrm{H} 22$ were drilled in Class I sweet spots zone near Well W31. After hydraulic fracturing, they all had high production. The daily peak productions were $77 \mathrm{t} / \mathrm{d}$ and $108 \mathrm{t} / \mathrm{d}$. The production test showed good development prospects for Class I sweet spots areas. It also verified the reliability of the source-reservoir chart method in the sweet spots evaluation. Therefore, it is suggested that the exploration direction should be shifted to the class I sweet spots zone in the southeast of the study area to achieve effective development and utilization of tight oil resources.

\section{Conclusion}

The overpressure caused by hydrocarbon generation is the bridge to connect the quality of source rock and reservoir for sweet spots evaluation of unconventional reservoirs. The combination of high-quality source rocks and the reservoirs with good properties can form high oil saturation sweet spots. Based on the data of hydrocarbon generation simulation experiment and mercury injection experiment, the equation of overpressure caused by hydrocarbon generation in the source formation is empirically fitted by TOC times Ro parameter. By converting mercury injection pressure data into source rock parameter, serials of oil saturations are plotted in the coordinate of porosity and TOC times Ro parameter to build the source-reservoir chart. In the application of the study area, by the combination of source rock and reservoir criteria, the chart is divided into three sweet spots zones and a non-sweet spots zone, and then the sweet spots of the study area are mapped. The production data verified the results and show the reliability of the chart method. This method provides a convenient and efficient procedure for evaluating sweet spots of tight oil based on integrating the quality of source rocks and reservoirs. 
Fig. 8 Sweet spots evaluation chart of the Jimsar's Lucaogou Formation. The upper sweet spots attributes come from the grids TOC times Ro and porosity value of the distribution map

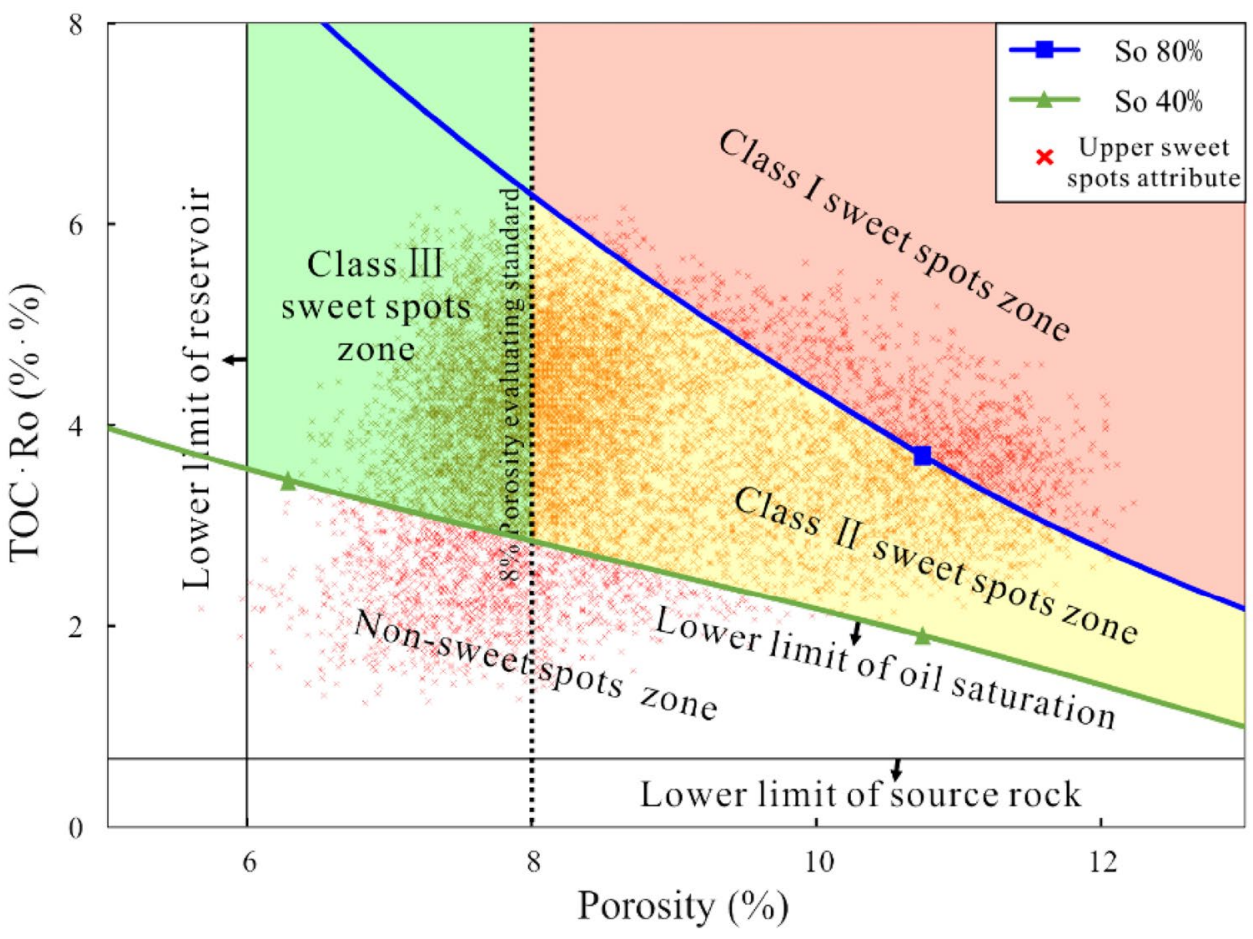

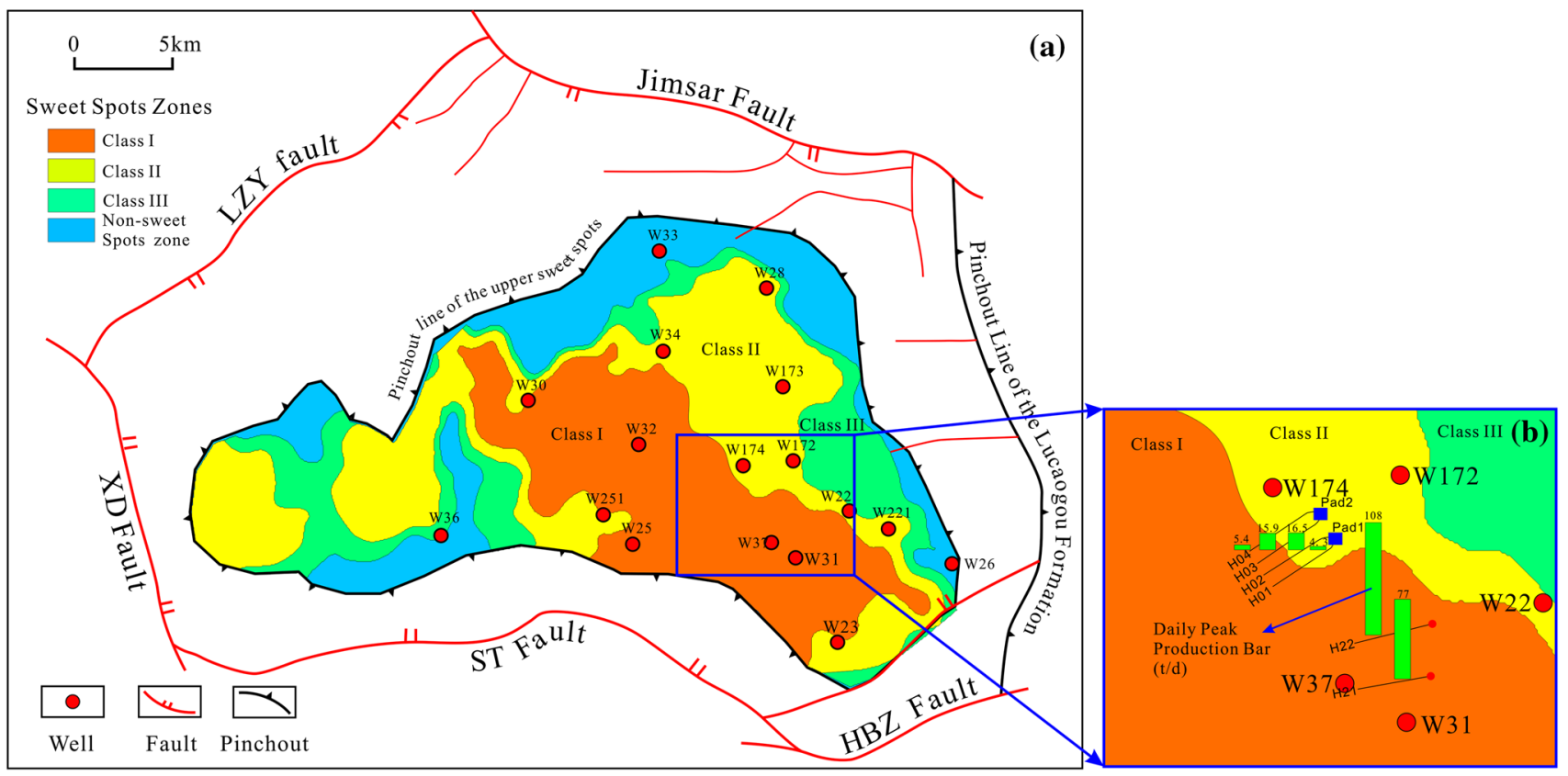

Fig. 9 a Evaluation map of the upper sweet spots of the Lucaogou Formation and $\mathbf{b}$ the daily peak production of the development pilot test area

Acknowledgements This research is supported by National Science and Technology Major Project (2016ZX05046002-004). The authors would like to thank the anonymous reviewers for the constructive comments.
Open Access This article is distributed under the terms of the Creative Commons Attribution 4.0 International License (http://creativeco mmons.org/licenses/by/4.0/), which permits unrestricted use, distribution, and reproduction in any medium, provided you give appropriate credit to the original author(s) and the source, provide a link to the Creative Commons license, and indicate if changes were made. 


\section{References}

Aliouane L, Ouadfeul SA (2014) Sweet spots discrimination in shale gas reservoirs using seismic and well-logs data. A case study from the worth basin in the Barnett shale. Energy Procedia 59:22-27

Berg RR, Gangi AF (1999) Primary migration by oil-generation microfracturing in low-permeability source rocks: application to the Austin Chalk. Texas AAPG Bull 83(5):727-756

Du J, Li J, Guo Ran BQ, Xu L, Liu G, Wang H, Lu Y (2016) China continental tight oil. Petroleum Industry Press, Beijing

Feng Z, Zhang S, Feng Z (2011) Discovery of enveloping surface of oil and gas overpressure migration in the Songliao Basin and its bearings on hydrocarbon migration and accumulation mechanisms. J Scientia sinica(terrae) 41(12):1872-1883

Guo X, He S, Song G, Wang X, Wang B, Li N, Luo S (2011) Evidences of overpressure caused by oil generation in Dongying Depression. Earth Sci J china Univ Geosci 36(6):1085-1094

Ju S, Zhao J, Bai Y (2014) Discussion on calculation method of hydrocarbon generation from hydrocarbon source rocks and its implications for research on tight oil accumulation dynamics. In: Shaan Xi Petroleum Society (ed) Unconventional oil and gas geology theory and exploration and development technology seminar in Ordos Basin, Xian, China, September 27

Kuang L, Gao G, Xiang B, Wang X, Wang C, Liu G (2014) Lowest limit of organic carbon content in effective source rocks from Lucaogou Formation in Jimusar Sag. Pet Geol Exp 36(2):224-229

Kuang L, Wang X, Guo X, Chang Q, Jia X (2015) Geological characteristics and exploration practice of tight oil of Lucaogou formation in Jimsar Sag. Xinjiang Pet Geol 36(6):629-634

Law C (1999) Evaluating Source Rocks. In: Exploring for Oil and Gas Traps. AAPG

Li M, LI J (2010) "Dynamic trap": a main action of hydrocarbon charging to form accumulations in low permeability-tight reservoir. $\mathbf{J}$ Acta Pet Sinica 31(5):718-722

Liu C (2015) Formation and preservation mechanism of sweet spot in tight clastic reservoirs - a case study of Chang 8 oil layer of Yanchang Formation in Zhenjing area, Southwest Ordos Basin. Oil Gas Geol 36(6):873-879

Ma S, Zhang Y (2017) Study on the pore structure of tight reservoir by using method of mercury injection - a case study of the Lucaogou Formation in Jimsar sag, Junggar Basin. Pet Geol Recovery Effic 24(1):26-33
Ma W, Wang D, Li Z, Du T (2013) A simulation experiment of pressurization during hydrocarbon generation from lacustrine source rocks. Acta Pet Sinica 34(s1):65-69

Nordeng SH (2009) The Bakken petroleum system: an example of a continuous petroleum accumulation. J N D Dep Miner Resour Newsl 36(1):21-24

Pang $\mathrm{Z}$ et al (2016) Simulation experiments of tight oil secondary migration driving force and resistance: a case study of Jurassic oilfield in middle Sichuan basin. J China Univ Min Technol 45(4):754-764

Tian J, Zeng X, Yi S, Guo Z, Gong Q (2016) The prediction method of the tight oil reservoirs "sweet spot" in saline lacustrine basin: a case study of the upper Ganchaigou Formation in the Zhahaquan district of Qaidam Basin. Earth Sci Front 23(5):193-201

Xu S, Mei L, Yuan C (1998) Numerical modeling on pressurizing caused by hydrocarbon generation. J Exp Pet Geol 20(3):85-89

Yang R, Zhao Z, Pang H, Li C, Qiu N, Song X (2012) Shale gas sweet spots: geological controlling factors and seismic prediction methods. Earth Sci Front 19(5):339-347

Yang Z, Hou L, Tao S, Cui J, Wu S, Lin S, Pan S (2015) Formation conditions and "sweet spot" evaluation of tight oil and shale oil. Pet Explor Dev 42(5):555-565

Zhang Y, Ma S, Gao Y, Li Y, Zhang J, Wang L, Sun Y, Xu F, Li H (2017) Depositional facies analysis on tight reservoir of Lucaogou Formation in Jimsar Sag. Junggar Basin Acta Sedimentol Sinica 35(2):358-370

Zhang H, Chen S, Zhang Y, Liu C, Lu J, Shi Z (2018) Research progress of the overpressure caused by hydrocarbon generation. Geol Sci Technol Inf 37(2):199-207

Zhou D, Jiao F (2012) Evaluation and prediction of shale gas sweet spots: a case study in Jurassic of Jiangnan area. Sichuan Basin Pet Geol Exp 34(2):109-114

Zou C, Dong D, Wang Y, Li XI, Huang J, Wang S, Guan Q, Zhang C, Wang H, Liu H et al (2015) Shale gas in china: characteristics, challenges and prospects (ii). Pet Explor Dev 43(2):182-196

Publisher's Note Springer Nature remains neutral with regard to jurisdictional claims in published maps and institutional affiliations. 